Original Research Articles

\title{
Diversity and abundance of culturable vibrionaceae in the rearing tanks of three different consumer types of aquaculture commodities
}

\author{
Hendra Munandar, Varian Fahmi, Syafriyadi Hafid, Dien Arista Anggorowati* \\ Research and Development Division for Marine Bio Industry-National Research and Innovation Agency (BRIN) Jalan Raya Senggigi, Teluk Kodek, \\ Malaka, North Lombok, West Nusa Tenggara, Indonesia
}

\begin{tabular}{ll} 
ARTICLE INFO & ABSTRACT \\
\hline $\begin{array}{l}\text { Article history: } \\
\text { Submitted } 30 \text { September } 2020\end{array}$ & $\begin{array}{l}\text { Vibrio spp. bacteria species are heterotrophic and halophilic bacteria, which are commonly found in } \\
\text { various habitats such as brackish, marine waters and animals. They are widely used as an indicator } \\
\text { of water quality and cultured animal health. This study investigates the diversity and abundance } \\
\text { occepted } 2 \text { November } 2021\end{array}$ \\
$\begin{array}{l}\text { of Vibrionaceae populations in the rearing water of three distinct consumer types of aquaculture } \\
\text { commodities, namely abalone, lobster and sea cucumber, during six months sampling. We isolated }\end{array}$ \\
$\begin{array}{l}\text { Keywords: } \\
\text { Vibrionaceae bacteria from the rearing tanks of three different consumer types of aquaculture } \\
\text { Vibrionaceae, }\end{array}$ \\
$\begin{array}{l}\text { commodities. We then inoculated } 100 \mu \text { L of undiluted to } 10^{-5} \text { diluted water samples onto petri dish } \\
\text { containing selective thiosulfate-citrate-bile salts-sucrose (TCBS) agar. We characterised bacteria } \\
\text { colonies based on the biochemical test for identification. Vibrio metschnikovii was the predominant } \\
\text { abundance, }\end{array}$ \\
$\begin{array}{l}\text { bacteria species in abundance value from the rearing water of cultured lobster and sea cucumber. } \\
\text { aquaculture, }\end{array}$ \\
$\begin{array}{l}\text { Meanwhile, Vibrio anguillarum was the most noticeable bacteria species in abundance from the } \\
\text { rearing water of cultured abalone. These data provide information and facilitate the risk assessment } \\
\text { of these pathogenic Vibrio species in aquaculture commodities. }\end{array}$
\end{tabular}

\section{Introduction}

The human population is expanding rapidly, which is directly related to the growing demand for food sources, including food derived from the sea. Therefore, aquaculture plays a vital role in providing sustainable food sources (BentzonTilia, Sonnenschein, \& Gram, 2016). In aquaculture, microorganisms play an essential role, particularly bacteria. Bacteria of the genus Vibrio are highly abundant in the marine environment that has two distinct roles, namely a positive role (nutrients recycling and organic matter degrading) and a negative role (parasite, infectious diseases) as well as the harmful role (Wendling et al., 2014). The application of artificial feed, high stocking density, excess food and low water quality leads to a high bacterial population, particularly pathogenic Vibrio. They are opportunistic pathogens, which can survive and multiply in the absence of their host, thus causing diseases in the aquaculture environment (Brown et al., 2012; "Defoirdt, 2016). Vibrio is responsible for disease and water-and foodborne pathogen (Ganesh et al., 2010). Vibriosis is the most common bacterial disease causing severe economic tolls in the aquaculture industry worldwide. Besides, the presence of specific human pathogenic species of Vibrio in the aquaculture environment can indicate public health safety of water and food that destined for human consumption (Lekshmy et al., 2014; Bentzon-Tilia et al., 2016; Cáceres-Martínez et al., 2019).

The Vibrionaceae family belongs to gram-negative Gammaproteobacteria which is ubiquitous in aquatic environments, including brackish, marine and sediments. They are usually motile rods and have a facultative fermentative metabolism. They generally grow on marine agar and the selective medium thiosulfate-citrate-bile salts-sucrose (TCBS) agar. They are primarily oxidase-positive (Mechri et al., 2012). The Vibrionaceae family has 142 classes and consists of 7 genera, including Alivibrio, Echinimonas, Enterovibrio, Grimontia, Photobacterium, Salinivibrio and Vibrio (Sawabe et al., 2013). Vibrio is a nutrient cycling agent that utilises dissolved organic compounds and the decomposition of an organic compound to provide simple biomolecules (Sherr \& Sherr, 2002). Vibrio species, a pathogen for marine biota, make its monitoring Vibrio in aquaculture processes crucial (Froelich et al., 2016; Nicolas et al., 2002). Several aspects of aquaculture, such as artificial feed, excessive stocking density, food surplus and poor water quality, contribute to a large bacterial population, especially the virulent Vibrio. They are opportunistic pathogens that may live and reproduce in the absence of their host, causing illnesses to aquaculture animals (Defoirdt, 2016). Several Vibrio species such as V.parahaemolyticus and $V$. variabilis was 
discovered to be in a significant number when skin ulceration diseases (SKUDs) occurred in sea cucumber Holothuria scabra. Other Vibrio species such as V. splendidus, V. cyclitrophicus, $V$. splendidus, $V$. harveyi and $V$. tasmaniensis are similarly affected by this condition in $A$. japonicus (Delroisse et al., 2020). Vibrio has also been discovered in crustaceans such as shrimp and lobster, as well as bivalve molluscs (Destoumieux-Garzón et al., 2020).

Vibrio is quickly attached to the particle in the water column, including animals (Baker-Austin et al., 2018). A previous study reported that seaweed was a reservoir for diverse Vibrio species, and several pathogens were reported in macroalgae (Barberi, 2020). Vibrio is also found in fish and shellfish with diverse concentrations and species (Austin \& Zhang, 2006; Beaz-Hidalgo et al., 2010). Vibrio with abundance concentration in the bottom waters (Ganesh et al., 2010; Plotieau et al., 2013). Seaweed was a food source for abalone farming, and fish was commonly used for lobster feeding. At the same time, sea cucumber utilises organic decomposition matter to complete its nutrition need (Mactavish et al., 2012; Robinson et al., 2019). Information about the difference of diverse Vibrio bacteria among these three consumer types at the trophic level is vital to support the aquaculture process. This study aims to provide the data and information about diversity, abundance and correlation Vibrio spp. in the rearing water of these three consumer types of animals.

\section{Materials and Methods}

\subsection{Seawater sampling}

Sampling was investigated from July 2017 to January 2018 at Aquaculture Laboratory of the Research and Development Division for Marine Bio Industry - Indonesian Institute of Sciences (LIPI), North Lombok, West Nusa Tenggara, Indonesia. Natural seawater was changed regularly with $50 \%$ of the total water volume twice a week and $100 \%$ of the total water volume once a week. The pumped seawater was filtered using sand and coral rubbles, seawater which source coming from Teluk Kodek seawater into these ponds. It allows water quality in each concrete pond to be similar to a natural condition. We regularly measured water quality parameters in the rearing tanks, such as $\mathrm{pH}$, temperature, salinity and dissolved oxygen (DO). We used three different cultured and trophic level species because these animals have been reared in this research institution for over five years and monitor pathogens mainly, the Vibrionacea in the rearing tanks. Lobsters were fed with fresh fish meat once daily, abalone were fed with fresh seaweed (Gracilaria sp.) ad libitum once daily and then sea cucumbers were fed with fermented seagrass pulp once daily. All of these animals were reared in \pm 300 L concrete ponds for each species. Water samples were collected aseptically in sterile containers $100 \mathrm{~mL}$, twice a month for seven months (July 2017 - January 2018) from rearing water of the adult stage or broodstock of lobster (Panulirus homarus), abalone (Haliotis squamata) and sea cucumber (Holothuria atra) ponds. Then, these samples were brought directly to the Microbiology Laboratory and adequately prepared for further detailed analysis.

\subsection{Bacterial isolation and characterisation}

Enumeration of Vibrio spp. was conducted by using serial dilution and plating method. Serial dilutions of the samples were performed using sterile seawater. Vibrio was isolated by inoculating $100 \mu \mathrm{L}$ of undiluted to $10^{-5}$ diluted water sample onto petri dish containing selective thiosulfate-citrate-bile salts-sucrose (TCBS) agar medium (Hi-Media Laboratories, Mumbai, India) containing $2 \% \mathrm{NaCl}$, specific for the Vibrionaceae biota in sterile seawater, followed incubation at $35{ }^{\circ} \mathrm{C}$ for $20-24 \mathrm{~h}$. The bacteria colonies were counted and the population density was expressed as colony-forming units (CFU) per mL. We selected all yellow, green and blue-green colonies for biochemical characterisation tests such as $0 \%, 3 \%, 6 \%, 8 \%$ and $10 \% \mathrm{NaCl}$ growth, motility, indole production and lysine ornithine decarboxylase (LDB), sucrose, glucose and fructose fermentation. These colonies were characterised based on the classical morphological and biochemical test, as described in Bergey's Manual of Systematic Bacteriology (Krieg \& Holt, 1984). We measured Vibrio bacterial diversities based on the Shannon diversity index, using the $\mathrm{H}^{\prime}=-\sum$ piln(pi) formula (Shannon, 1984). Shannon's index of evenness was calculated according to E $=\mathrm{H}^{\prime} / \operatorname{lnS}$, where $\operatorname{lnS}$ represents H'max. Statistical differences among the bacteria diversity and evenness indexes in rearing tanks of different trophic level species commodities were performed by ANOVA analysis, followed by the least significant difference (LSD) test. Pearson's correlation measured the number of bacteria colonies in the rearing tank of three different level trophic species and sampling months. P-value $<0.05$ and P-value $<0.01$ being accepted as a significant level using IBM SPSS version 27 software for Windows.

\section{Results}

\subsection{Water quality parameters}

Water quality parameters data showed a lower tendency occurred in three months of the wet season. Characteristics of sampled rearing water are measured physically, biologically and chemically in Table 1.

Table 1. Physical, biological and chemical characteristics of sampled rearing water in aquaculture tanks.

\begin{tabular}{|c|c|c|c|c|c|}
\hline \multirow{2}{*}{ Sampling month } & \multicolumn{5}{|c|}{ Water quality parameters } \\
\hline & Temperature $\left({ }^{\circ} \mathrm{C}\right)$ & $\mathrm{pH}$ & Salinity $(\%)$ & Dissolved Oxygen (DO) (mg/L) & Total Vibrio (CFU/100 mL) \\
\hline August 2017 & $29 \pm 1.03$ & $8 \pm 0.2$ & $34 \pm 0.7$ & $7.2 \pm 0.5$ & $6.5 \times 10^{3}-1.9 \times 10^{4}$ \\
\hline September 2017 & $29 \pm 1.04$ & $8 \pm 0.3$ & $34 \pm 0.4$ & $7.5 \pm 0.3$ & $2.1 \times 10^{3}-2.03 \times 10^{4}$ \\
\hline October 2017 & $28 \pm 1.08$ & $8 \pm 0.2$ & $33 \pm 0.5$ & $6.8 \pm 0.4$ & $1.8 \times 10^{2}-2.1 \times 10^{3}$ \\
\hline November 2017 & $27 \pm 0.7$ & $8 \pm 0.1$ & $33 \pm 0.2$ & $7 . .4 \pm 0.2$ & $6.5 \times 10^{2}-8.2 \times 10^{3}$ \\
\hline December 2017 & $27 \pm 1.01$ & $7.8 \pm 0.3$ & $32 \pm 0.6$ & $6.5 \pm 0.3$ & $7.1 \times 10^{2}-5.2 \times 10^{3}$ \\
\hline January 2018 & $27 \pm 0.9$ & $7.8 \pm 0.5$ & $32 \pm 0.1$ & $7 \pm 0.1$ & $5.1 \times 10^{2}-6.1 \times 10^{3}$ \\
\hline
\end{tabular}

Data are presented as means \pm SD. 
Table 2. Diversity bacteria of the family Vibrionaceae in the rearing water of lobster, abalone and sea cucumber evaluated by Shannon's diversity index $\left(\mathrm{H}^{\prime}\right)$, species evenness (E') and species richness (S).

\begin{tabular}{llll}
\hline Aquaculture commodity species & Shannon diversity index $\left(\mathrm{H}^{\prime}\right)$ & Shannon evenness index $\left(\mathrm{E}^{\prime}\right)$ & Species richness $(\mathrm{S})$ \\
\hline Lobster (Panulirus homarus) & $2.02^{\mathrm{a}}$ & $0.71^{\mathrm{a}}$ & $17^{\mathrm{a}}$ \\
Abalone (Haliotis squamata) & $2.03^{\mathrm{a}}$ & $0.77^{\mathrm{a}}$ & $14^{\mathrm{a}}$ \\
Sea cucumber (Holothuria atra) & $1.56^{\mathrm{b}}$ & $0.59^{\mathrm{b}}$ & $14^{\mathrm{a}}$ \\
\hline
\end{tabular}

Different letters indicate significant differences among three different cultured species commodities $(P<0.05)$ using the LSD test.

The $\mathrm{pH}$ was highly stable thoroughout the six months. Meanwhile, temperature and salinity tended to decrease in November, December and January. The higher temperature was found in August, September and October. On the other hand, lower salinity values were associated with heavy rain in the wet/rainy season.

Total Vibrionaceae populations in rearing water of three different trophic level species demonstrated higher populations of Vibrionaceae occurred in August and September, while other four months presented lower Vibrionaceae populations than two previous months. During the six months, the value of dissolved oxygen in the rearing water of three different trophic level species showed slight fluctuations.

\subsection{Shannon's diversity index of Vibrionaceae bacteria}

The diversity and evenness of the Vibrionaceae populations in the rearing water of lobster and abalone were moderate for all sampling occasions. However, sea cucumber's diversity and evenness indexes were significantly lower than lobster and abalone (Table 2). The diversity index of lobster and abalone was 2.02 and 2.03 , respectively. The lowest value of diversity index was shown in sea cucumber, which was 1.56. Meanwhile, the evenness index values of Vibrionaceae populations in rearing water of lobster and abalone were not a significant difference, and it was 0.71 and 0.77 , respectively. The contrary result was shown to the evenness index value of Vibrionaceae populations in the rearing water of sea cucumber with a remarkable distinction compared to others, which was 0.56 . The number of distinctive Vibrionaceae species in the rearing water of lobster was 17 , followed by rearing water of abalone and sea cucumber which were 14 .

\subsection{Identification and comparison of culturable Vibrionaceae}

Vibrionaceae species in the rearing water of cultured lobster (Panulirus sp.) demonstrated that Vibrio metschnikovii was the most incredible relative abundance. Then, it was followed by the lowest number of Vibrionaceae colonies, which was Vibrio damsela (Fig.1). Some bacterial species from the Vibrionaceae and Aeromonadaceae families were found only in the rearing water samples of the lobster tanks, which was Vibrio comitans, Vibrio damsela, Aeromonas salmonicida biovar masoncida and Aeromonas molluscorum (Fig.1). In the rearing water of abalone (Haliotis asinina) sample, Vibrio anguillarum showed the highest relative abundance value, followed by $V$. metschnikovii, $V$.vulnificus, V.parabaemolyticus and V.alginolyticus. However, the smallest relative abundance value of Vibrio bacteria was Vibrio pacinii (Fig. 2). Interestingly, Vibrio proteolyticus was only found in the abalone (Haliotis asinina) tank; however, it was not obtained in the rearing water sample of other cultured animals tanks (Fig. 3). A similar result of prominent Vibrio species from rearing water of lobster, Vibrio metschnikovii was found in the rearing water of sea cucumber as well. Two different Vibrio species with the most negligible relative abundance were discovered in the rearing water of sea cucumber. It was Vibrio brasillensis and Aeromonas salmonicida (Fig. 3). Vibrio agarivorans and Vibrio angustum were two specific Vibrio species found only in the rearing water of cultured sea cucumber.

The difference of Vibrionaceae colony number in three different consumer types during six months has presented that Vibrionaceae bacteria populations in the rearing water of lobster were the highest in August and September, then decreased sharply in October. At the same time, those Vibrionaceae populations differ significantly compared to two other cultured animals, namely abalone and sea cucumber (Fig. 4). The number

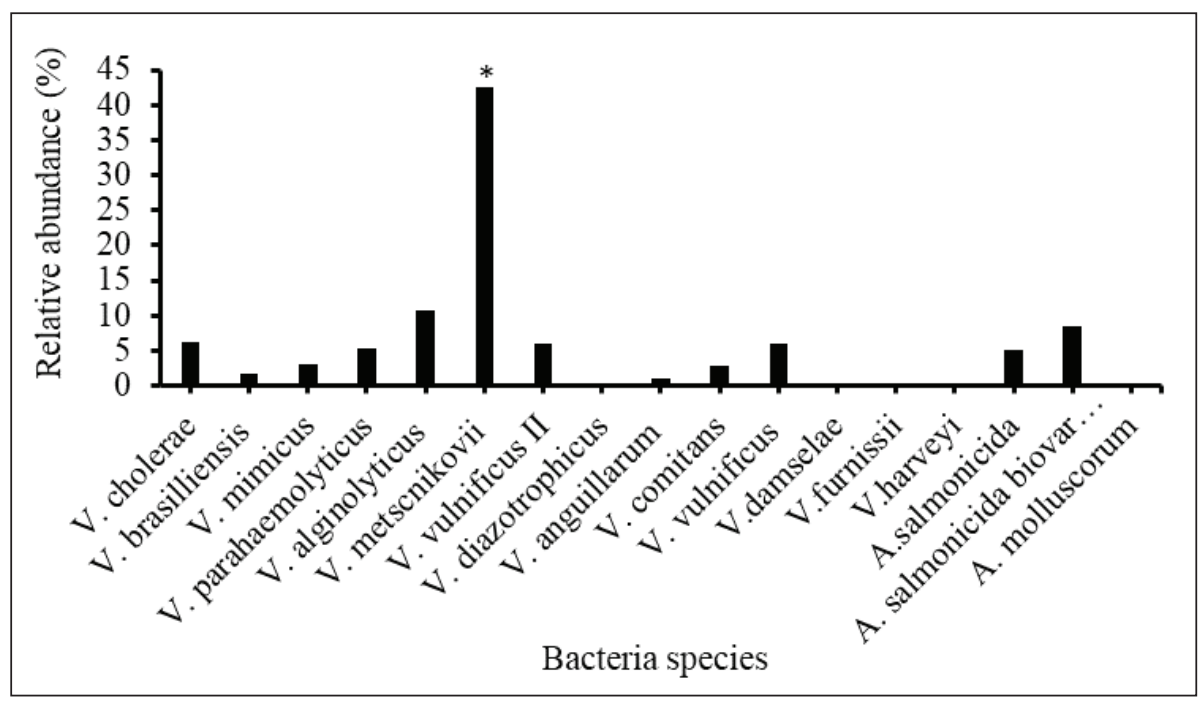

Fig. 1. Relative abundance of Vibrionaceae species in the rearing water of cultured lobster (Panulirus homarus). 


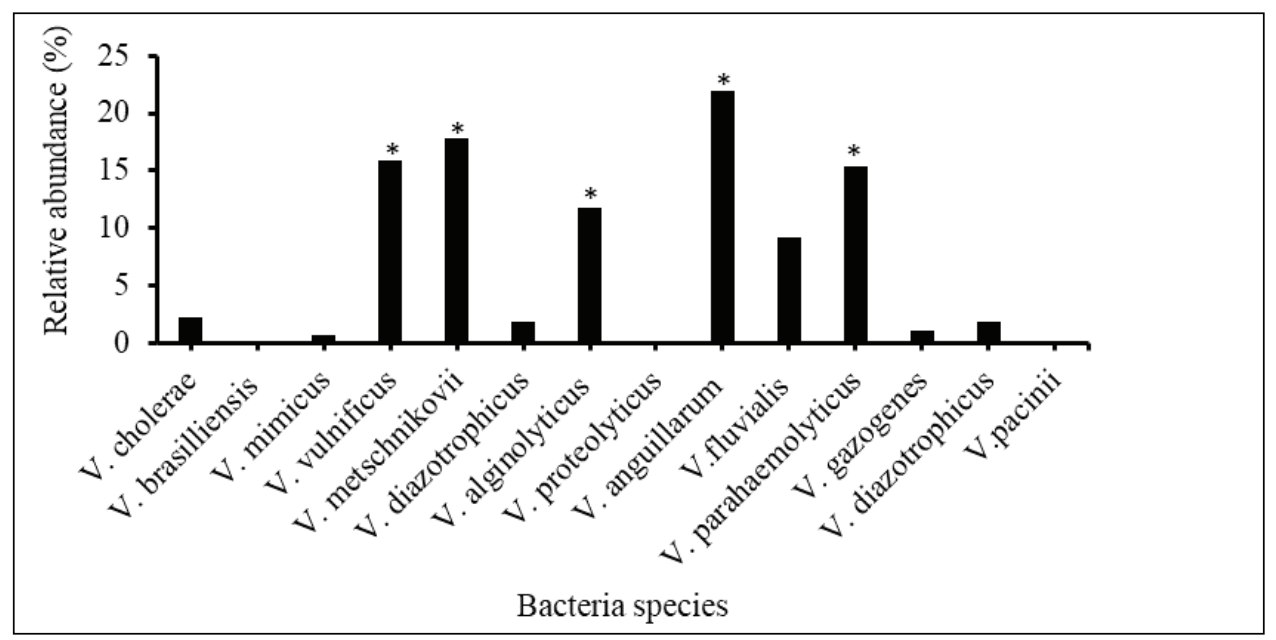

Fig. 2. Relative abundance of Vibrionaceae species in the rearing water of cultured abalone (Haliotis asinina).

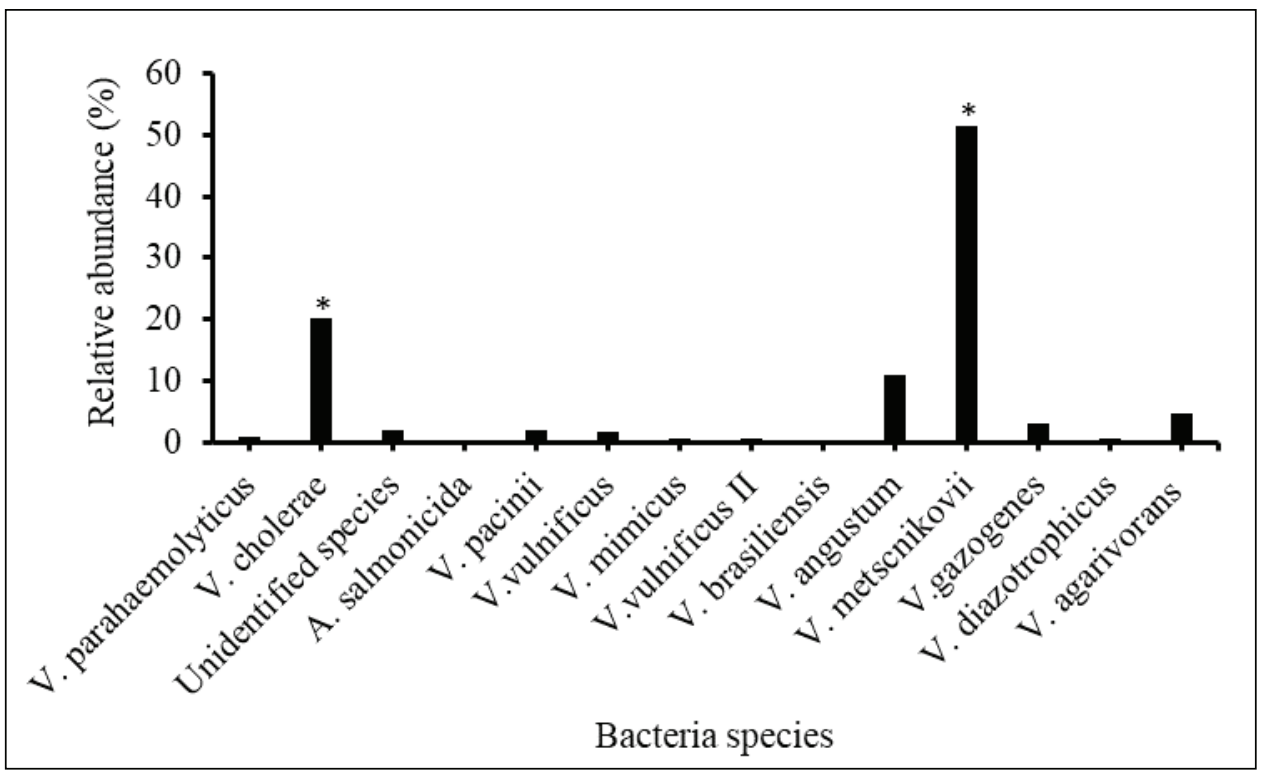

Fig.3. Relative abundance of Vibrionaceae species in the rearing water of cultured sea cucumber (Holothuria atra).

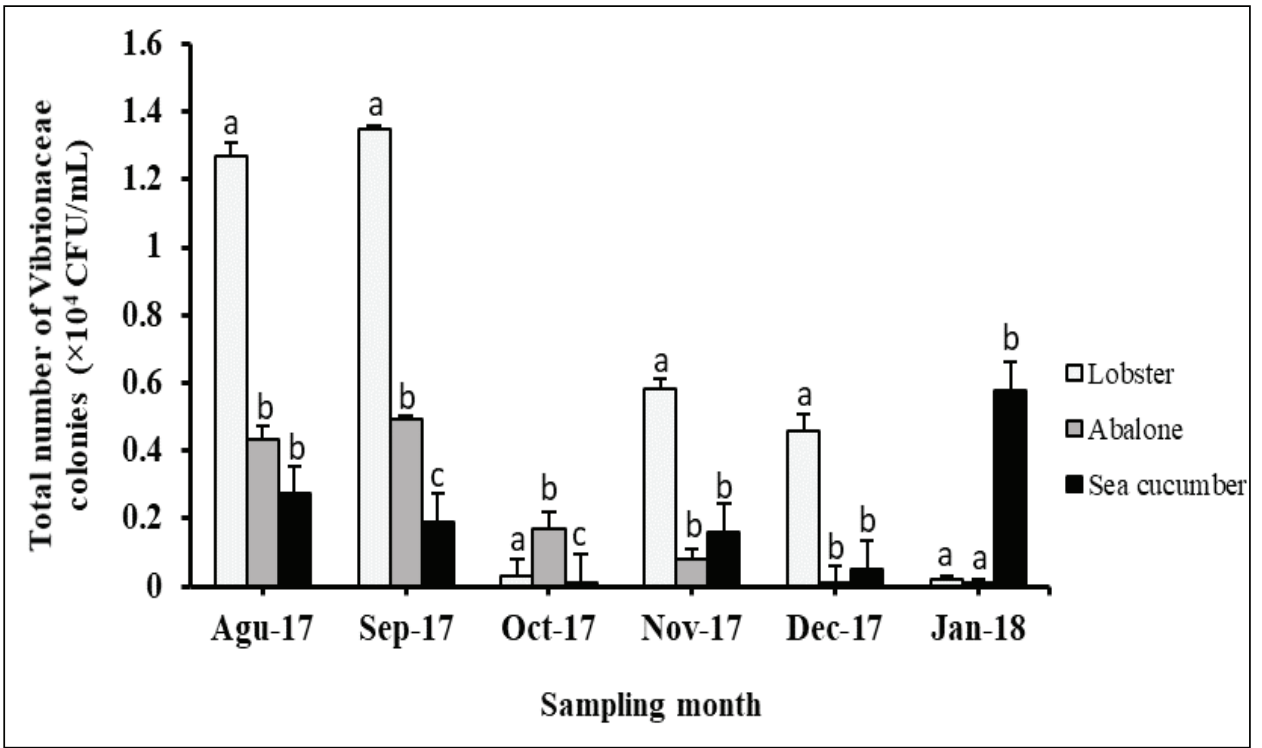

Fig. 4. Fluctuations of Vibrionaceae populations in different sampling months and rearing seawater tanks of different cultured animal species 
of Vibrionaceae populations in the rearing water of abalone tended to drop gradually during six months of sampling. In contrast, the highest number of Vibrionaceae populations in the rearing water of sea cucumber was found only in January. All results of Vibrionaceae populations number in distinct rearing water of three different consumer types of aquaculture commodities and sampling month showed a decreasing tendency in bacteria population number from August to January. However, only in January, did the Vibrionaceae populations in rearing water of cultured sea cucumber rise sharply.

\subsection{Correlation between Vibrionaceae abundance and water quality}

Pearson's correlation analysed that Vibrionaceae abundance and water quality parameters represented a highly positive relationship between Vibrionaceae abundance in the rearing water of cultured lobster and abalone and water quality parameters such as temperature and salinity during sampling month. However, Pearson's correlation index showed a significantly negative relationship between Virionaceae abundance in the rearing water of culture sea cucumber and water quality parameters during sampling month, which were -0.12 and -0.18 for temperature and salinity, respectively (Table 3).

\section{Discussion}

Data of water quality parameters demonstrated that temperature and salinity values slightly declined for three months during the rainy season. Even though its value was relatively low, it probably promoted some chemical, physical and biological changes in the rearing water column. Consequently, those changes may impact the diversity, abundance, richness of the microbiota community, particularly the Vibrionaceae family, in the rearing water of cultured animals. Some previous studies regarding the effect of water quality on aquatic animal health and microbiota community in aquaculture activities have been investigated. According to Takemura et al. (2014), there may be ecological relationships between Vibrio and plankton, while salinity and temperature showed different patterns between total Vibrio and individual species and within each other species. In natural aquatic environments, bacteria communities respond rapidly to changes and may lead to activation or inactivation of their particular metabolic pathway in composition and functionality.

Shannon's diversity and abundance index of Vibrionaceae populations in the rearing water of cultured lobster and abalone showed moderate species diversity and abundance. These results differed from Vibrionaceae populations in the rearing water of cultured sea cucumber, which was slightly lower (1.56 and $0.59)$. It was interesting data as to be known that sea cucumber is a deposit feeder and a decomposer biota type, which uses high bacteria concentration for degrading organic matter from sediment, faeces and detritus. However, these index values, Vibronaceae diversity and abundance in the rearing water of cultured sea cucumber presented the contrary and the lowest one. These results may occur because the populations of Vibrionaceae in the rearing water of cultured sea cucumber may be filtered by sea cucumber and collected in their gut or body colon. These results showed in agreement with previous studies that sea cucumber obtain food by filtration of seawater or by ingestion of marine sediment (Ward-Rainey et al., 1996). Besides, these results also revealed that water quality did not strongly influence Vibronaceae diversity and abundance in the rearing water of cultured sea cucumber because of its feeding behaviour.

The distinct biological-types consumers of cultivated species in aquaculture tanks probably influence bacteria density and variation species in rearing water samples of cultured species. The highest bacterial populations in the rearing water of farmed lobster may be related to the accumulation of nitrogenous compounds or protein particles concentration from faeces and the excess feed of fresh fish meat as its food. In the water column and sediment, these organic matters are then decomposed by aerobic heterotrophic bacteria, including the Vibrionaceae family, to their metabolism and growth (Naeem \& Li, 1998; Hargreaves, 1998). Hargreaves (1998) described that ammonia is released as the end product of protein catabolism, and it may be toxic if allowed to accumulate in aquaculture ponds. Vibrio metschnikovii, a bacteria species with the highest density in the rearing water of cultured lobster is described microbiologically as gram-negative, catalase-positive and oxidase-negative, slightly curved rods and opaque colonies 2 to $3 \mathrm{~mm}$ in diameter. It can be found in various aquatic habitats such as lakes, marine waters, sewage and marine biota, for instance, shrimp, crabs and shellfish (Linde et al., 2004). Human infection by V. metschnikovii based on human clinical samples, in contrast, is an infrequent event. Despite a deadly rare case, this bacteria can lead to a fatal human infection such as severe septic shock, cardiac arrest, septicaemia and wound infection (Jensen \& Jellinge, 2014; Linde et al., 2004; Hansen et al., 1993). The previous study reported that V. metschnikovii produce protease enzyme (Jellouli et al., 2009). This enzyme is probably used to degrade protein particles of feeds and faeces waste sources in the rearing water column. Interestingly, some Vibrio bacteria were only found in the rearing water of cultured lobster; 1 . Vibrio comitans produce alginase enzyme (Sawabe et al., 2007), 2. Vibrio damsela produce the cytolytic toxin, which causes wound infection to humans as well as pathogenic to marine animals (Hundenborn et al.,

Table 3. Pearson's correlation index between Vibrionaceae abundance and two vital parameters of water quality.

\begin{tabular}{lll}
\hline \multirow{2}{*}{ Cultured species } & Pearson's correlation index \\
\cline { 2 - 3 } & Temperature $\left({ }^{\circ} \mathrm{C}\right)$ & Salinity $(\%)$ \\
\hline Lobster & $0.76^{\mathrm{a}}$ & $0.82^{\mathrm{a}}$ \\
Abalone & $0.98^{\mathrm{a}}$ & $0.95^{\mathrm{a}}$ \\
Sea cucumber & $-0.12^{\mathrm{b}}$ & $-0.18^{\mathrm{b}}$ \\
\hline
\end{tabular}

Different letters indicate significant differences among three different cultured species commodities $(P<0.05)$. 
2013; Rivas et al., 2013; Akram et al., 2015), 3. Aeromonas salmonicida biovar masoucida and Aeromonas molluscorum, the two Aeromonas genus members are ubiquitous, water-borne bacteria, predominantly pathogenic to poikilothermic animals and humans. In human infection, these bacteria from mesophilic strains can cause gastroenterics (Tomás, 2012; Janda \& Abbott, 2010; Igbinosa et al., 2012; Miñana-Galbis et al., 2004).

Vibrio bacteria density in rearing water of cultured sea cucumber showed a lower bacterial density. It may be affected by the biological consumer type of sea cucumbers (Holothuria atra), which is detrivores (deposit-feeding or consuming particulate matter, including bacteria). Hence, a high concentration of Vibrio populations in the rearing water was probably fed by sea cucumbers. Those results demonstrated in an agreement that sea cucumbers obtain food by filtration of seawater as well as the ingestion of large quantities of marine sediment (Gao et al., 2014; Plotieau et al., 2013; Lin et al., 2016). Sea cucumbers play a crucial role in the marine ecosystem in the recycling and remineralisation of organic matters by bioturbation and feeding in reef sands (Purcell et al., 2016; Lee et al., 2017). However, according to Plotieau et al. (2013), sea cucumbers significantly differ in microhabitat and behaviour among species. Furthermore, Vibrio metschnikovii were found predominant density in the rearing water of farmed sea cucumber (Holothuria atra), a similar result with notable Vibrio species density in the rearing water of cultured lobster. Vibrio metschnikovii was found in all of the rearing water samples of different farmed animals, including reservoir as control. These obtained results revealed that this bacteria species is a natural heterotrophic bacteria inhabitant, which is ubiquitous in marine waters and infected sea animals and has been well-known as a causative agent with virulence gene expresses (Jensen \& Jellinge, 2014; Hansen et al., 1993). Unlike previous results of the outstanding Vibrio species densities in rearing water of cultured lobster and sea cucumber, Vibrio anguillarum is the highest Vibrio species density found in the rearing water of farmed abalone. $V$. anguillarum is described as a Gram-negative and comma-shaped rod bacterium belonging to the Vibrionaceae family. It is polarly flagellated halophilic and facultatively anaerobic halophilic bacteria. Furthermore, $V$. anguillarum is the causative agent of vibriosis, a deadly haemorrhagic septicaemic disease affecting various marine, fresh or brackish water fish, molluscs and crustaceans. This disease, vibriosis, is responsible for severe economic losses worldwide (Frans et al., 2011; Gao et al., 2018; Larsen et al., 2004). Some previous studies reported that there are 12 Vibrio species have been implicated in human infections, however, particularly $V$. cholerae, $V$. parahaemolyticus, $V$. alginolyticus and $V$. vulnificus are certainly the most frequently isolated species in human diseases (Hansen et al., 1993; Dalsgaard, 1998; Baker-Austin et al., 2018; Wang et al., 2015; Latinoamericana de et al., 2007). There was a correlation relationship between Vibrionaceae diversity and water quality. These data were in accordance with a previous study that stated temperature and salinity correlate strongly to the Vibrionaceae population in an aquaculture environment (Takemura et al., 2014). However, the previous study reported that some major factors substantially influence the distribution of Vibrio species, such as geographic location, water temperature and salinity (Tey et al., 2015). In the aquaculture system, the pathogenic Vibrio bacteria density in aquaculture tanks should be controlled under $1000 \mathrm{CFU} \mathrm{mL}^{-1}$ (Ganesh et al., 2010).

\section{Conclusion}

The current study reveals the diversity and abundance of Vibrionaceae species in the rearing water of three different consumer types of cultured commodities, as well as its correlation to the aquaculture environment. Some pathogenic Vibrio species were found in the rearing water of three different consumer types of cultured commodities. It can be vital information to prevent mass mortality and diseases outbreak in aquaculture activities. These bacteria are common in the natural water environment, however, they could be pathogenic bacteria to animals and humans as well. While, Vibrioalginolyticus, Vibrioparabaemolyticus, and Vibriovulnificus are the most causative Vibrio species.

\section{References}

Abdelaziz, M., Ibrahem, M. D., Ibrahim, M. A., Abu-Elala, N. M., \& Abdel-moneam, D. A. (2017). Monitoring of different Vibrio species affecting marine fishes in Lake Qarun and Gulf of Suez: Phenotypic and molecular characterisation. Egyptian Journal of Aquatic Research, 43(2), 141-146. https://doi.org/10.1016/j. ejar.2017.06.002

Akram, A., Stevens, R. P., \& Konecny, P. (2015). Photobacterium damselae and Vibrio harveyi hand infection from marine exposure. The Medical Journal of Australia, 203(5), 224-225. https://doi.org/10.5694/mja15.00179

Azim, M.E. and Little, D. C. (2006). Intensifying aquaculture production through new approaches to manipulating natural food Environmental Monitoring and Impact Assessment for major developments (energy, mining, infrastructure) View project Effects of $\mathrm{C} / \mathrm{N}$ controlled periphyton based organic f. CAB Reviews: Perspective in Agriculture, Veterinary Science, Nutrition and Natural Resources, 1(062), 1-23. https://doi. org/10.1079/PAVSNNR20061062

Baker-Austin, C., Oliver, J. D., Alam, M., Ali, A., Waldor, M. K., Qadri, F., \& Martinez-Urtaza, J. (2018). Vibrio spp. infections. Nature Reviews Disease Primers, 4(1). https://doi.org/10.1038/ s41572-018-0005-8

Bentzon-Tilia, M., Sonnenschein, E. C., \& Gram, L. (2016). Monitoring and managing microbes in aquaculture - Towards a sustainable industry. Microbial Biotechnology, 9(5), 576-584. https://doi. org/10.1111/1751-7915.12392

Breed, R. S., Murray, E. G. D.Smith, N. R. (1957). Bergey's Manual of Determinative Bacteriology (Seventh Ed). Baltimore, USA: The Williams and Wilkins, (pp.356).

Brown, S. P., Cornforth, D. M., \& Mideo, N. (2012, July 1). Evolution of virulence in opportunistic pathogens: Generalism, plasticity, and control. Trends in Microbiology, 20, 336-342. https://doi. org/10.1016/j.tim.2012.04.005

Cáceres-Martínez, J., Yeomans, R. V., \& Cruz-Flores, R. (2019). Bacteriological water quality of recirculating aquatic systems for maintenance of yellowtail amberjack Seriola lalandi. Article in Journal of the World Aquaculture Society. https://doi. org/10.1111/jwas. 12620

Cunningham, L. (2005). Assessing the contribution of aquaculture to food security: a survey of methodologies. FAO Fisheries Circular, 1010, $1-25$.

Dalsgaard, A. (1998). The occurrence of human pathogenic Vibrio spp. and Salmonella in aquaculture. International Journal of Food Science and Technology, 33, 127-138.

Defoirdt, T. (2016). Implications of Ecological Niche Differentiation in Marine Bacteria for Microbial Management in Aquaculture to 
Prevent Bacterial Disease. PLOS Pathogens, 12(11), e1005843. https://doi.org/10.1371/journal.ppat.1005843

Flores, O., Belanche, L. A., \& Blanch, A. R. (2009). New multiplatform computer program for numerical identification of microorganisms. Journal of Clinical Microbiology, 47(12), 4133-4135. https://doi.org/10.1128/JCM.01250-09

Frans, I., Michiels, C. W., Bossier, P., Willems, K. A., Lievens, B., \& Rediers, H. (2011). Review Vibrio anguillarum as a fish pathogen : virulence factors, diagnosis and prevention. Journal of Fish Diseases, 34, 643-661. https://doi.org/10.1111/j.13652761.2011.01279.x

Ganesh, E. A., Das, S., Chandrasekar, K., Arun, G., \& Balamurugan, S. (2010). Monitoring of Total Heterotrophic Bacteria and Vibrio Spp. in an Aquaculture Pond. Current Research Journal of Biological Sciences, 2(1), 48-52. Retrieved from https://www. researchgate.net/publication/267606862

Gao, F., Li, F., Tan, J., Yan, J., \& Sun, H. (2014). Bacterial Community Composition in the Gut Content and Ambient Sediment of Sea Cucumber Apostichopus japonicus Revealed by $16 \mathrm{~S}$ rRNA Gene Pyrosequencing. PLOS ONE, 9(6). https://doi. org/10.1371/journal.pone.0100092

Gao, X., Pi, D., Chen, N., Li, X., Liu, X., Yang, H., ... Zhang, X. (2018). Survival, Virulent Characteristics, and Transcriptomic Analyses of the Pathogenic Vibrio anguillarum Under Starvation Stress. Frontiers in Cellular and Infection Microbiology, 8, 389. https:// doi.org/10.3389/fcimb.2018.00389

Gupta, P., Samant, K., \& Sahu, A. (2012). Isolation of cellulosedegrading bacteria and determination of their cellulolytic potential. International Journal of Microbiology. https://doi. org $/ 10.1155 / 2012 / 578925$

Hansen, W., Freney, ' J, Benyagoub, H., Letouzey, M.-N., Gigi, J., \& Wauters2, G. (1993). Severe Human Infections Caused by Vibrio metschnikovii. Journal of Clinical Microbiology, 31(9), 2529-2530. Retrieved from http://jcm.asm.org/

Hargreaves, J. A. (1998). Nitrogen biogeochemistry of aquaculture ponds. Aquaculture, 166, 181-212.

Hundenborn, J., Thurig, S., Kommerell, M., Haag, H., \& Nolte, O. (2013). Severe Wound Infection with Photobacterium damselae ssp. Damselae and Vibrio harveyi, following a laceration injury in marine environment: A case report and review of the literature. Case Reports in Medicine, 2013, 1-7. https://doi. org/10.1155/2013/610632

Igbinosa, I. H., Igumbor, E. U., Aghdasi, F., Tom, M., \& Okoh, A. I. (2012). Emerging Aeromonas species infections and their significance in public health. The Scientific World Journal, 2012. 1-13. https://doi.org/10.1100/2012/625023

Janda, J. M., \& Abbott, S. L. (2010, January 1). The genus Aeromonas: Taxonomy, pathogenicity, and infection. Clinical Microbiology Reviews, 23, 35-73. https://doi.org/10.1128/CMR.00039-09

Jellouli, K., Bougatef, A., Manni, L., Agrebi, R., Siala, R., Younes, I., \& Nasri, M. (2009). Molecular and biochemical characterisation of an extracellular serine-protease from Vibrio metschnikovii J1. Journal of Industrial Microbiology and Biotechnology, 36(7), 939-948. https://doi.org/10.1007/s10295-009-0572-5

Jensen, J., \& Jellinge, M. E. (2014). Severe septic shock and cardiac arrest in a patient with Vibrio metschnikovii: A case report. Journal of Medical Case Reports, 8(1), 348. https://doi.org/10.1186/17521947-8-348

Khalil, R. H., \& Abd El-Latif, H. M. (2013). Effect of Vibrio Alginolyticus on Mugil Capito. Journal of the Arabian Aquaculture Society, 8(1), 193-204.

Larsen, M. H., Blackburn, N., Larsen, J. L., \& Olsen, J. E. (2004). Influences of temperature, salinity and starvation on the motility and chemotactic response of Vibrio anguillarum. Microbiology, 150(5), 1283-1290. https://doi.org/10.1099/mic.0.26379-0

Latinoamericana de, R., Noriega-Orozco, L., Acedo-Félix, E., HigueraCiapara, I., Jiménez-Flores, R., Cano, R., \& Guaymas, A. (2007). Pathogenic and non pathogenic Vibrio species in aquaculture shrimp ponds. Rev Latinoam Microbiol, 49(3-4), 60-67. Retrieved from www.medigraphic.com

Lee, S., Ferse, S., Ford, A., Wild, C., \& Mangubhai, S. (2017). Effect of sea cucumber density on the health of reef-flat sediments In S. Mangubbai, W. Lalavanua and S.W. Purcell (eds.). Fiji's Sea Cucumber Fishery: Advances in Science for Improved Management, Report No. 01/17. Suva, Fiji .pp. 54-61.

Lehane, S. (2013). Fish for the Future: Aquaculture and Food Security. Future Directions International, August, 1-8.

Lekshmy, S., Mohandas, M., \& Radhakrishnan, T. (2014). Monitoring of Vibrio parahaemolyticus in Aquaculture Ponds, Kerala, India. In International Journal of Science and Research. Retrieved from http://www.fda.gov/Food/ScienceResearch/LaboratoryMeth

Lin, J., Ju, B., Yao, Y., Lin, X., Xing, R., Teng, L., ... Jiang jal, A. (2016). Microbial community in a multi-trophic aquaculture system of Apostichopusjaponicus, Styela clava and microalgae. Aquacult Int, 24, 1119-1140. https://doi.org/10.1007/s10499-016-9975-2

Linde, H.-J., Kobuch, R., Jayasinghe, S., Reischl, U., Lehn, N., Kaulfuss, S., \& Beutin, L. (2004). Vibrio metschnikovii, a Rare Cause of Wound Infection. Journal of Clinical Microbiology, 42(10), 4909-4911. https://doi.org/10.1128/JCM.42.10.49094911.2004

Linde, H. J., Kobuch, R., Jayasinghe, S., Reischl, U., Lehn, N., Kaulfuss, S., \& Beutin, L. (2004). Vibrio metschnikovii, a rare cause of wound infection. Journal of Clinical Microbiology, 42(10), 4909-4911. https://doi.org/10.1128/JCM.42.10.49094911.2004

Mente, E., Pierce, G. J., Santos, M. B., \& Neofitou, C. (2006). Effect of feed and feeding in the culture of salmonids on the marine aquatic environment: A synthesis for European aquaculture. Aquaculture International, 14(5), 499-522. https://doi. org/10.1007/s10499-006-9051-4

Miñana-Galbis, D., Farfán, M., Fusté, M. C., \& Lorén, J. G. (2004). Aeromonas molluscorum sp. nov., isolated from bivalve molluscs. International Journal of Systematic and Evolutionary Microbiology, 54(6), 2073-2078. https://doi.org/10.1099/ ijs. $0.63202-0$

Naeem, S., \& Li, S. (1998). Consumer species richness and autotrophic biomass. Ecology, $79(8), 2603-2615$. https://doi. org/10.1890/0012-9658(1998)079[2603:CSRAAB]2.0.CO;2

Plotieau, T., Lavitra, T., Gillan, D. C., \& Eeckhaut, I. (2013). Bacterial diversity of the sediments transiting through the gut of Holothuria scabra (Holothuroidea; Echinodermata). Marine Biology, 160, 3087-3101. https://doi.org/10.1007/ s00227-013-2297-2

Purcell, S., Uthicke, S., \& Byrne, M. (2016). Ecological Roles of Exploited Sea Cucumbers Impact of climate change on marine invertebrates View project Population ecology of freshwater mussels View project. Oceanography and Marine Biology: An Annual Review, 54, 367-386. https://doi.org/10.1201/9781315368597-8

Rimmer, M. A., Sugama, K., Rakhmawati, D., Rofiq, R., \& Habgood, R. H. (2013). A review and SWOT analysis of aquaculture development in Indonesia. Reviews in Aquaculture, 5(4), 255-279. https://doi.org/10.1111/raq.12017

Rivas, A. J., Lemos, M. L., \& Osorio, C. R. (2013). Photobacterium damselae subsp. damselae, a bacterium pathogenic for marine animals and humans. Frontiers in Microbiology, 4(SEP), 283. https://doi.org/10.3389/fmicb.2013.00283 
Sawabe, T., Fujimura, Y., Niwa, K., \& Aono, H. (2007). Vibrio comitans sp. nov., Vibrio rarus sp. nov. and Vibrio inusitatus sp. nov., from the gut of the abalones Haliotis discus discus, $H$. gigantea, $H$. madaka and H. rufescens. International Journal of Systematic and Evolutionary Microbiology, 57(5), 916-922. https://doi. org/10.1099/ijs.0.64789-0

Schwarz, W. H. (2001). The cellulosome and cellulose degradation by anaerobic bacteria. Applied Microbiology and Biotechnology, Vol. 56, pp. 634-649. https://doi.org/10.1007/s002530100710

Tey, Y. H., Jong, K. J., Fen, S. Y., \& Wong, H. C. (2015). Occurrence of Vibrio parabaemolyticus, Vibrio cholerae, and Vibrio vulnificus in the aquacultural environments of Taiwan. Journal of Food Protection, 78(5), 969-976. https://doi.org/10.4315/0362028X.JFP-14-405

Tomás, J. M. (2012). The Main Aeromonas Pathogenic Factors . ISRN Microbiology, 2012, 1-22. https://doi. org/10.5402/2012/256261

Wang, R., Zhong, Y., Gu, X., Yuan, J., Saeed, A. F., \& Wang, S. (2015). The pathogenesis, detection, and prevention of Vibrio parahaemolyticus. Frontiers in Microbiology, 6(3), 1-13. https:// doi.org/10.3389/fmicb.2015.00144

Wendling, C. C., Batista, F. M., \& Wegner, K. M. (2014). Persistence, Seasonal Dynamics and Pathogenic Potential of Vibrio Communities from Pacific Oyster Hemolymph. PLoS ONE, 9(4), 94256. https://doi.org/10.1371/journal. pone.0094256

\section{Declarations}

\section{Funding statement}

This research did not receive any specific grant from funding agencies in the public, commercial, or not-for-profit sectors.

\section{Conflict of interest}

The authors declare no known conflict of financial interest or personal relationships that could have appeared to influence the work reported in this paper.

\section{Additional information}

Reprints and permission information is available at https:// mri.lipi.go.id

Publisher's Note: Indonesian Institute of Sciences remains neutral with regard to jurisdictional claims in published maps and institutional affiliations. 